\title{
M-politics: Credibility and effectiveness of mobile political communications
}

Received (in revised form): 10th December, 2007

\section{Maria Irene Prete}

is completing a PhD programme in Economics and Quantitative Methods for Market Analysis at the University of Salento, and is carrying out research activities in Marketing and Territorial Marketing at the same university, as well as in Market Analysis and Research at LUISS University (Rome). She also holds a Science Master (Master Recherche) in Management (Science de Gestion), a specialisation in Marketing, at Ecole Doctorale Economie, Gestione et Espace of Paris XII University, ESCP-EAP, and Ecole Centrale Paris (France).

Keywords political marketing, new media, credibility, mobile politics, SMS communications, voting intention

Abstract New communication technologies and, in particular, SMS (Short Message Service) - that is, undersized text messages sent to a mobile phone by a computer or by another mobile device offer political parties and candidates an innovative tool for communicating with their actual and prospective voters. The present study evaluates both credibility and its effects on the voting intention of SMS political communication (ie mobile-politics, M-Politics), by considering credibility as a characteristic ascribed to SMS. The results indicate that although m-politics is considered a credible tool, with regard to their effect on the voting intention, it does not modify the intention to vote but rather reinforces the past voting behaviour of both Center-Right and Center-Left voters. Consequently, they do not allow political parties and candidates to grasp opposing coalition voters and change their voting intention, but only to enhance the loyalty of actual voters.

Journal of Targeting, Measurement and Analysis for Marketing (2007) 16, 48-56. doi:10.1057/palgrave.jt.5750063

\section{INTRODUCTION}

The recent evolution concerning the political panorama and media system has been influencing both the relationship among voters and political actors, and their ways of communicating. In particular, the use of political marketing - that is, marketing procedure and techniques for the achievement of electoral objectives ${ }^{1}$ - and the consequent implementation of permanent political campaigns $^{1}$ have pointed out the importance, in the political arena, of communication activity. Additionally, the introduction and mass diffusion of

Correspondence: Maria Irene Prete, University of Salento, Lecce (Italy), LUISS, Roma, Italy.

Tel: +3933822357989

Fax: +390832298729

E-mail: ireneprete@libero.it
Information and Communication Technologies, including internet and mobile telephony, have stimulated the use of nontraditional media for the transmission of political information. ${ }^{2}$

Among these new tools, mobile politics ( $m$ politics) can be defined as the diffusion of political information and advertising, by the use of mobile telephony, both by citizens and by political actors. With m-politics it is possible to implement Viral Political Marketing, a technique of political communication intended for the viral propagation of messages about parties, candidates and political events. ${ }^{2}$ Although numerous international experiences testify to the efficacious application of mobile communications, evaluation methods of their ability to achieve electoral objectives have not yet been developed. ${ }^{2}$

The present study aims to estimate the credibility and effects on the voting intention of 
SMS (Short Message Service) - that is, undersized text messages sent to a mobile phone by a computer or by another mobile device - used by political actors. The findings indicate that although most voters consider m-politics a credible tool for political communications, its effect on their voting intention depends on numerous factors, such as voters' political affiliations, attitudes and beliefs.

\section{CREDIBILITY OF POLITICAL COMMUNICATION}

Political communication includes all kinds of communication carried out by political actors to accomplish particular electoral purposes, directed to them by nonpoliticians, and also communication about them and their activities. ${ }^{3,4}$ For political communication to achieve its principal objective — informing, persuading and acting — it needs to possess a high degree of credibility, a characteristic ascribed to its source (source credibility), defined as the degree to which individuals rely on their communicator. ${ }^{5,6}$ Credibility identifies a positive characteristic of communication, which contributes to influencing the audience favourably once they receive messages.

A credible person is supposed to have a profound knowledge of a specific theme (expertise), to be reliable (trustworthiness) and to lead to a process of identification with the source (attractiveness). ${ }^{7}$ Thus, according to the existing literature, mobile communications can be considered credible if they have the following characteristics:

- Trustworthiness: It is the perceived goodness of a specific source that satisfies some expectations, such as trust, honesty, motivations, values and convictions; ${ }^{8}$ mobile communications can be considered trustworthy if they allow users to have a clear and immediate idea about their purpose and their source. That is, when they have a definite and transparent identity.

- Expertise: It is a structured set of effective knowledge, skills, behaviour/attitudes for the development of a task; mobile messages can be considered expert if they provide a straightforward interaction both for expert users and novices, demonstrate usefulness and easiness, and allow users to find the information they need.

- Attractiveness: It is linked to a process of identification with the source, that is, a change of attitude motivated by the desire to establish a gratifying relationship with the source and appear to be psychologically almost near the same. ${ }^{9}$ Mobile communications can be judged to be attractive if they manage to capture the interest of users, arousing an emotional and instinctive response.

\section{RESEARCH OBJECTIVES}

The aim of this research is to verify the credibility and effectiveness of $\mathrm{m}$-politics, and more specifically, it has the following objectives: (i) verifying whether SMS can be considered a credible tool for communicating political messages; (ii) evaluating the perceived credibility of two specific SMS political messages, one sent by the Italian Center-Right coalition and the other one sent by the Italian Center-Left coalition during a political campaign; and (iii) evaluating the effects of $\mathrm{m}$-politics on the voting intention of both CenterRight and Center-Left voters.

It is hypothesised that Center-Left voters consider m-politics as a credible tool for political communications more than Center-Right voters do. Furthermore, Italian voters consider more credible an SMS political message transmitted from their own coalition, thus evidencing a selective exposure effect, as people tend to give more attention to and to process information according to their own attitudes and beliefs. Concerning their influence on voters' behaviour, SMS messages do not modify the intention to vote, but rather reinforce the past voting behaviour of both Center-Right and Center-Left voters. These hypotheses are now considered in more detail.

$\mathbf{H}_{1}$ : $\quad$ SMS messages, used as political communication media, are considered more credible from Center-Left voters compared to Center-Right voters. 
Personality traits - stable characteristics and the qualities of the way of thinking, predisposing one to certain habitual behaviours ${ }^{10}$ - and moral values — ideal references that serve as guide principles in one's life ${ }^{11}$ — influence voters' decisions more than other sociodemographic characteristics like age, income, education and profession. ${ }^{12-14}$ As concerns personality traits, examined through the Five Factors Model $^{15,16}$ — which describes human personality as composed of five dimensions (Openness to Experience, Conscientiousness, Extraversion, Agreeableness and Neuroticism) - Center-Left voters possess a high level of Openness to Experience - intellectual curiosity, an interest in being informed about new things, and a favourable attitude toward cultural diversity and lifestyles with respect to Center-Right voters. ${ }^{13}$ As regards moral values, evaluated through Schwartz's values structure model, ${ }^{11}$ Center-Left voters possess a high level of Autodirection, which refers to action and independent thought. ${ }^{13,14}$ Center-Right voters possess a high level of Conformism - which refers to the limitation of one's actions, propensities and impulses, and is included in the dimension of Conservatism, implying a tendency to accept traditions. ${ }^{13,14}$ These differences give reason to hypothesise that Center-Left voters consider m-politics more credible with respect to Center-Right voters.

$\mathbf{H}_{2}$ : Voters consider more credible SMS messages, used as political communication media, when sent by the supported coalition, rather than SMS messages sent by the opposing coalition.

The communication process produces a relationship between the recipient and the sender of a specific political message. This relationship is not only regarding the message content but also the context, which includes political affiliation, gender, ethnicity and the level of audience receptiveness. ${ }^{4}$ Voters select, perceive and memorise only information coherent with their political orientation, and furthermore they tend to perceive only what they intend to perceive. ${ }^{4}$ Supporters of a certain coalition generally partake of their political representatives' world view: they have the same interpretation of facts concerning political and economical issues, propose similar solutions and evidence the same dominant decoding. Loyal voters tend to consider only political ads referring to the particular party or candidate they prefer, taking into account the issues and fragments of communication they consider relevant, without considering the points and arguments given by their opponents. ${ }^{4,17}$

\section{$\mathbf{H}_{3}$ : $\quad$ SMS messages used as political} communication media do not change the voting intention of either voters supporting or not supporting the candidate's coalition that sent the message.

Only a limited margin of voters are efficaciously influenced by political ads and are consequently induced to modify their voting intention. ${ }^{18}$ In the occurrence of political communication diffused by an opposing coalition, voters adopt an oppositional decoding, refusing both the values and the specific message content. In fact, voters have a closure attitude toward partisan perceived information, and are inclined to interpret it in an unfavourable way. ${ }^{4}$ Furthermore, when considering negative advertising diffused by the preferred coalition, some studies evidence that it could produce a two-fold weakening effect, including both a 'boomerang effect' - implying a negative evaluation of the message sender - and a 'victimisation syndrome' - entailing a positive evaluation of the attacked candidate, as a consequence of the negative communication. ${ }^{19}$ These effects are, however, more likely when negative communications are perceived as exaggerated or unfaithful, for example when containing attacks on the candidate's personal life. ${ }^{19}$

\section{$\mathbf{H}_{4}$ : $\quad$ SMS messages, used as political communication media, reinforce the voting intention of voters supporting the candidate's coalition that sent the message.}

Mass media, while not directly influential, because of mediating factors, such as audience predisposition, do have a reinforcing effect. ${ }^{4,20}$ Political communication can reinforce existing 
political attitudes and behavioural models, and, in particular, negative advertising can have a reinforcing effect on the voting intention of partisan voters. ${ }^{21}$ It provides less involved and less informed voters with reinforcement and security, and furthermore, it offers more involved and more informed voters with security through the coherence of the diffused messages. ${ }^{20}$

\section{METHODOLOGY}

A questionnaire was administered to a sample of 480 subjects, divided into: (i) a sub-sample of Center-Right voters, composed of 51.7 per cent males and 48.3 per cent females, in the following age groups: 34.6 per cent (18-27 y.o.), 22.5 per cent (28-39 y.o.), 19.2 per cent (40-51 y.o.), 12.9 per cent (52-63 y.o.) and 10.8 per cent (more than 64 y.o.); (ii) a sub-sample of Center-Left voters, composed of 51.3 per cent males and 48.7 per cent females, in the following age groups: 37.9 per cent (18-27 y.o.), 23.3 per cent (28-39 y.o.), 13.8 per cent (40-51 y.o.), 14.6 per cent (52-63 y.o.) and 10.4 per cent (more than 64 y.o.). Thus, there are no major differences between the groups considered with respect to age and gender.

The questionnaire contained three screening questions and four different sections. The first two screening questions have allowed for the selection of the subjects considering both the use of a mobile telephony ('Do you have a mobile telephone?') and of SMS ('Do you regularly make use of receiving and sending text messages SMS (Short Message Service?) (If not, close the interview'); the third question has allowed for the division of voters into two sub-samples ('Currently, are you a Center-Right or a CenterLeft voter?'). The first section of the questionnaire contained: (i) the measurement of voting intention on a seven-point scale; (ii) the measurement of perceived credibility of SMS as political media, by means of the Ohanian sevenpoint scale, ${ }^{2}$ which evaluates the different dimensions of Attractiveness (Unattractive/ Attractive, Not Classy/Classy, Ugly/Beautiful, Plain/Elegant, Not Sexy/Sexy), Trustworthiness (Undependable/Dependable, Dishonest/Honest, Unreliable/Reliable, Insincere/Sincere, Untrustworthy/Trustworthy) and Expertise (Not an Expert/Expert, Inexperience/Experienced, Unknowledgeable/Knowledgeable, Unqualified/ Qualified, Unskilled/Skilled). The second section contained the measurement of the perceived credibility - by using a seven-point scale — of two different SMS messages: one sent by the Center-Right coalition, led by Berlusconi, and the other one from the Center-Left coalition, led by Prodi. The messages were sent during the last political campaign for the re-election of the Italian Parliament, on 9th and 10th April , 2006. The first SMS message was concerned with the fact that the Center-Left coalition included in its political programme 'the re-introduction of the death tax for large patrimonies', abolished by the Center-Right coalition with the Budget Law in 2001. In the days before elections, the Center-Right coalition, sent voters an SMS having the following text:

'Prodi taxes the others because he has already given: act 16/5/2003 rep. 94916 fasc. 21915 notary Vico. Together with his wife Franzoni Flavia, he has given their sons Giorgio and Antonio 870.000 Euro tax free'.

The second SMS message, diffused by CenterLeft activists, refers to the approval of Law 05.12.2005, n. 251, the so-called ex-Cirielli Law, because the deputy Edmondo Cirielli, after having proposed it, voted against it. This law introduced some modifications to the penal code, allowing Berlusconi to avoid a trial for corruption. It has the following text:

Voters have observed arrogance of a power which has not hesitated to enact ad personam laws in order to save the President and his friends. So immodesties the law that even the person who created the first draft is ashamed and disowns it: today the Cirielli Law is called ex-Cirielli.

In order to evaluate the similarity between the two messages, an ANOVA was conducted on a stratified sample of 80 voters, considering as a dependent variable the importance of the two messages considered. No difference was registered between the two messages. The third section included the measurement of the effects on voting intention, by means of a seven-point scale, and in particular: (i) the change of one's voting intention ('If you had received this SMS, would 
have you changed your voting intention?'); (ii) the perceived change of Center-Right and Center-Left voters' intention ('How much do you think that this SMS has changed the voting intention of Center-Right voters?', 'How much do you think that this SMS has changed the voting intention of Center-Left voters?'); (iii) the reinforcement of Center-Right and Center-Left voters' intention ('How much do you think that this SMS has reinforced the voting intention of Center-Left voters?', 'How much do you think that this SMS has reinforced the voting intention of Center-Right voters?'); and (iv) the weakening of the voting intention of partisan voters' intention ('How much do you think that this SMS has weakened the voting intention of Center-Right voters?', 'How much do you think that this SMS has weakened the voting intention of Center-Left voters?'). The fourth section contained the sociodemographic data.

\section{ANALYSIS AND RESULTS}

In order to test Hypothesis $\mathrm{H}_{1}$, by considering the 15 attributes of the Ohanian scale, ${ }^{7}$ two factor analyses - the first one on the Center-Right sample and the second one on the Center-Left sample - were conducted, using the principal component analysis method and the Oblimin rotation. ${ }^{22}$ The results obtained are summarised in Tables 1 and 2 .

In order to test Hypothesis $\mathrm{H}_{2}$, two ANOVAs were conducted considering as a dependent variable the question on 'Credibility of SMS'. The results evidenced that Center-Right voters judge as more credible the SMS message sent by their own coalition $(\mu=5.350 ; \delta=1.453 ; p<0.05)$ with respect to Center-Left voters $(\mu=3.425 ; \delta=1.476$; $p<0.05$ ) (see Table 3). Analogously, Center-Left voters consider more credible the SMS message sent by their preferred coalition, $(\mu=5.541$; $\delta=1.639 ; p<0.05)$, with respect to Center-Right voters $(\mu=2.375 ; \delta=1.640 ; p<0.05)$ (see Table 4 ).

Verification of Hypotheses $\mathrm{H}_{3}$ and $\mathrm{H}_{4}$ was carried out by considering separately the two messages. Regarding the effect on the voting intention of the SMS sent by the Center-Right coalition, three ANOVAs were conducted (see Table 5). The first one, using as a dependent variable the question regarding the "Change of One's Voting Intention', produced a $p$-value $<0.05$, and very low means both for Center-Right $(\mu=1.408 ; \delta=0.983)$ and for Center-Left voters $(\mu=2.075 ; \delta=1.251)$. The second ANOVA, using as a dependent variable

Table 1: Factor loadings for Center-Right voters

\begin{tabular}{|c|c|c|c|c|c|}
\hline $\begin{array}{l}\text { Factor } 1 \\
\text { expertise }\end{array}$ & Coeff. & $\begin{array}{l}\text { Factor } 2 \\
\text { trustworthiness }\end{array}$ & Coeff. & $\begin{array}{l}\text { Factor } 3 \\
\text { attractiveness }\end{array}$ & Coeff. \\
\hline 1. Knowledgeable & 0.807 & 1. Unreliable & -0.908 & 1. Sexy & 0.702 \\
\hline 2. Expert & 0.792 & 2. Dishonest & -0.756 & 2. Elegant & 0.640 \\
\hline 3. Experienced & 0.734 & 3. Insincere & -0.721 & 3. Classy & 0.629 \\
\hline 4. Qualified & 0.663 & 4. Untrustworthy & -0.663 & 4. Attractive & 0.541 \\
\hline 5. Skilled & 0.594 & & & 5. Beautiful & 0.382 \\
\hline 6. Dependent & 0.408 & & & & \\
\hline
\end{tabular}

Note: Total variance explained from the three factors is $56.402 \%$; Expertise explains a variance of $40.683 \%$; Trustworthiness explains a variance of $8.288 \%$; Attractiveness explains a variance of $7.43 \%$.

Table 2: Factor loadings for Center-Left voters

\begin{tabular}{llllll}
\hline Factor $\mathbf{1}$ attractiveness & Coeff. & Factor $\mathbf{2}$ trustworthiness & Coeff. & Factor $\mathbf{3}$ expertise & Coeff. \\
\hline 1. Knowledgeable & 0.831 & 1. Classy & 0.791 & 1. Sincere & 0.653 \\
2. Expert & 0.766 & 2. Beautiful & 0.762 & 2. Trustworthy & 0.651 \\
3. Experienced & 0.737 & 3. Elegant & 0.614 & 3. Honest & 0.618 \\
4. Skilled & 0.644 & 4. Attractive & 0.592 & 4. Reliable & 0.601 \\
5. Qualified & 0.609 & & & 5. Dependable & 0.591 \\
\hline
\end{tabular}

Note: Total variance explained from the three factors is $63.407 \%$; Attractiveness explains a variance of $45.428 \%$; Trustworthiness explains a variance of $7.937 \%$, and Expertise explains a variance of $7.489 \%$. 
the question considering the 'Perceived Change of the Voting Intention of Center-Left voters', showed a $p$-value $<0.05$, and a mean for CenterRight voters $(\mu=3.100 ; \delta=1.541)$ to some extent higher than the mean of Center-Left voters $(\mu=2.483 ; \delta=1.378)$. The third ANOVA, considering as a dependent variable the question concerning 'Weakening of the Voting Intention of Center-Right voters', produced a nonsignificant $p$-value, $p>0.05$, showing a nonstatistically significant difference, as Center-Right voters produced a very low mean $(\mu=2.150 ; \delta=1.493)$,

Table 3: ANOVA Credibility of SMS message sent by the Center-Right coalition

\begin{tabular}{|c|c|c|c|c|}
\hline \multirow{2}{*}{$\begin{array}{l}\text { Political } \\
\text { orientation }\end{array}$} & \multirow{2}{*}{$\begin{array}{l}\text { Mean } \\
(\mu)\end{array}$} & \multirow{2}{*}{$\begin{array}{l}\text { Standard } \\
\text { deviation } \delta\end{array}$} & \multicolumn{2}{|l|}{ ANOVA } \\
\hline & & & $\boldsymbol{F}$ & $p$ \\
\hline $\begin{array}{l}\text { Center-Right } \\
\text { voters }\end{array}$ & 5.350 & 1.453 & 103.631 & 0.000 \\
\hline $\begin{array}{l}\text { Center-Left } \\
\text { voters }\end{array}$ & 3.425 & 1.476 & & \\
\hline
\end{tabular}

Table 4: ANOVA Credibility of SMS message sent by the Center-Left coalition

\begin{tabular}{|c|c|c|c|c|}
\hline \multirow{2}{*}{$\begin{array}{l}\text { Political } \\
\text { orientation }\end{array}$} & \multirow{2}{*}{$\begin{array}{l}\text { Media } \\
(\mu)\end{array}$} & \multirow{2}{*}{$\begin{array}{l}\text { Standard } \\
\text { deviation }(\delta)\end{array}$} & \multicolumn{2}{|l|}{ ANOVA } \\
\hline & & & $\boldsymbol{F}$ & $p$ \\
\hline $\begin{array}{l}\text { Center-Right } \\
\text { voters }\end{array}$ & 2.375 & 1.640 & 223.774 & 0.000 \\
\hline $\begin{array}{l}\text { Center-Left } \\
\text { voters }\end{array}$ & 5.541 & 1.639 & & \\
\hline
\end{tabular}

as did Center-Left voters $(\mu=1.900 ; \delta=1.032)$. In order to test Hypothesis $\mathrm{H}_{4}$, an additional ANOVA was conducted, using as a dependent variable the question considering 'Reinforcement on the Voting Intention of Center-Right voters'. The analysis produced a $p$-value $<0.05$, and a mean for Center-Right voters $(\mu=5.391$; $\delta=1.493)$ higher than Center-Left voters $(\mu=4.525 ; \delta=1.032)$.

Analogously, the same analysis was conducted for measuring the effects on the voting intention of the SMS sent by the Center-Left coalition; similar results were obtained (see Table 6).

\section{GENERAL DISCUSSION}

The results concerning the evaluation of SMS perceived credibility as political communication media verify Hypothesis $\mathrm{H}_{1}$. Center-Right voters consider SMS a qualified and attractive media, as the factors of Expertise and Attractiveness suggest, but at the same time consider it to be a nontrusted medium for pursuing the determined electoral objectives, as the dimension of untrustworthiness evokes. They judge m-politics as a scarcely credible tool, confirming a weak proclivity toward innovative communication media (internet and mobile telephony) and a tendency to prefer traditional political media (radio, television, press). Moreover, a number of other studies have also evidenced that Right-wing voters possess a high level of conformism and

Table 5: ANOVA Related to the SMS message sent by the Center-Right coalition

\begin{tabular}{|c|c|c|c|c|}
\hline Variables & $\begin{array}{l}\text { Center-Right } \\
\text { voters mean }(\mu)\end{array}$ & $\begin{array}{l}\text { Center-Left } \\
\text { voters mean }(\mu)\end{array}$ & Test $\boldsymbol{F}$ & $p$ \\
\hline Change of voting intention & 1.408 & 2.075 & 21.063 & 0.000 \\
\hline Perceived change of the voting intention of Center-Left voters & 3.100 & 2.483 & 10.674 & 0.001 \\
\hline Weakening of the voting intention of Center-Right voters & 2.150 & 1.900 & 2.276 & 0.133 \\
\hline Reinforcement of the voting intention of Center-Right voters & 5.391 & 4.525 & 18.800 & 0.000 \\
\hline
\end{tabular}

Table 6: ANOVA Related to the SMS message sent by the Center-Left coalition

\begin{tabular}{llrr}
\hline Variables & $\begin{array}{l}\text { Center-Right } \\
\text { voters mean }(\boldsymbol{\mu})\end{array}$ & $\begin{array}{l}\text { Center-Left } \\
\text { voters mean }(\boldsymbol{\mu})\end{array}$ & Test $\boldsymbol{F}$ \\
\hline Change of voting intention & 2.125 & 1.700 & 7.624 \\
Perceived change of the voting intention of Center-Right voters & 2.466 & 0.006 \\
Weakening of the voting intention of Center-Left voters & 2.300 & 9.133 & 0.002 \\
Reinforcement of the voting intention of Center-Left voters & 3.208 & 2.200 & 2.982 \\
\hline
\end{tabular}


conservatism, a scarce openness to novelty, a limited tendency to search for new stimuli, sensations and new experiences. ${ }^{13,14}$ Conversely, Left-wing voters consider SMS communications not only an attractive but also a trustworthy and expert medium, which political actors can efficaciously use to diffuse information and advertising. This result is coherent with the particular characteristics of Center-Left voters, as they have a high level of openness to novelty, ${ }^{12,14}$ thus evidencing a tendency towards nontraditional communication media.

The analysis conducted for the verification of Hypothesis $\mathrm{H}_{2}$ confirmed this, thus showing that the use of a particular SMS political message produces a greater stimulus in individuals having a sense of affiliation with and sharing the ideology of the coalition source of the message. These results are coherent both with the initial studies on selective exposure - the tendency to give more attention and process information of one's preferred party or candidate ${ }^{10}$ — and with recent studies, showing that advertising effects depend on voters' political attitudes and beliefs. ${ }^{4,18}$ The high level of credibility attributed to the message sent by the Center-Right coalition $(\mu=3.42)$ can be considered in the light of voters' particular interest and anxiety about the reintroduction of a tax. Recent research illustrates that communication media exert a selective exposure based not only on ideological or partisan differences, but mainly on specific issues. Voters usually apply a utility-based or egocentric selection, based on the subjective relevance of each single issue. Consequently, a message having a content that voters consider significant is able to reach the audience more efficaciously and will be considered more credible.

Hypothesis $\mathrm{H}_{3}$, concerning the change of the voting intention induced from SMS political messages, is confirmed, thus evidencing that both messages do not significantly modify the voting intention of both partisan and nonpartisan voters. Specifically, the SMS political message sent by the Center-Right coalition did not increase the voting intention of nonpartisan voters, showing relatively low means $(\mu=2.075 ; \mu=2.483)$, as well as the SMS message sent by the Center-Left coalition $(\mu=2.125 ; \mu=2.466)$. These results represent an evaluation element useful for political marketing consultants: negative advertising used through SMS messages in order to acquire additional shares of the electorate through the vilification of the opposing candidate or party can generate scarce results, especially if advertising is perceived as exaggerated or unfair. ${ }^{19}$ Furthermore, neither SMS political messages weakens the voting intention of partisan voters, as the nonsignificant statistically difference and low means evidenced ( $\mu=1.408$ for Right-wing voters, and $\mu=1.700$ for Left-wing voters). These results showed the absence of both the so-called 'boomerang effect' and the 'victimisation syndrome'.

Hypothesis $\mathrm{H}_{4}$, related to the reinforcement of the voting intention of partisan electors, was confirmed for both the messages considered. Specifically, considering the message sent by the Center-Right coalition ANOVA evidenced a mean for partisan voters $(\mu=5.390)$ higher than that involving Center-Left voters $(\mu=4.525)$. Similarly, the message sent by the Center-Left coalition showed a mean for partisan voters $(\mu=4.600)$ higher than that for Center-Left voters $(\mu=3.200)$. The results suggest that individuals judge the reinforcement effect of partisan messages more considerably than that of nonpartisan messages, thus evidencing a tendency to underestimate the ability of a specific message to influence the voting intention of opposing coalition voters. SMS political messages appear to be particularly efficacious only to intensify the voting intention of loyal voters, ${ }^{21}$ and to produce a stimulus in people having a sense of affiliation with the ideology of the message sender. ${ }^{1}$ The influential power of $\mathrm{m}$-politics efficaciously involves loyal voters, giving rise to a higher perceived credibility and a reinforcement effect, but lacks the ability to increase or weaken the voting propensity for a certain coalition.

\section{IMPLICATIONS AND CONCLUSIONS}

The present study suggests both theoretical and operational implications. The findings confirm the 
need to investigate the effectiveness of mobile marketing as communication media in the different cultural, political and environmental contexts. Although m-politics obtained efficacy and consensus in various political experiences such as in the Philippines, Kenya and partially in Hungary - it is essential to consider their credibility and effects on a case-by-case basis in the different international contexts. Message communication entails a decoding, which can be influenced by different factors, such as political affiliation, interest in specific issues and the media, all of which contribute to the creation of the subjective political reality, that is, the perceived reality of events and the country's public situation. Identification of these factors is relevant both for academicians and for marketing consultants and political actors.

The Italian experience in 2006 showed that, although SMS messages were considered credible, they had only a moderate effect on the voting intention, reflecting outcomes produced in other experiences. During the political election in Great Britain in 2001, where the main objective of SMS employment was the reduction of abstention of young voters, this media did not influence voters' attitudes, as turnout bottomed out at a level of 59 per cent. Furthermore, 78.6 per cent of the interviewed subjects considered SMS messages useless and not persuasive, and 84.4 per cent perceived them as unreliable., ${ }^{2,20}$ Other studies also found that, when used for commercial purposes, mobile technology is often perceived as untrustworthy and intrusive.

The reinforcement effect on the voting intention evidenced that consultants and political actors can efficaciously use m-politics to reach both loyal and undecided voters, and, consequently, to reduce the volatility of unstable voters (swing voters), a largely diffused phenomenon in modern Western democracies. ${ }^{23}$ The strengthening of voters' loyalty is necessary for both the parties and the candidate, as they can have more flexibility to change their policies and also establish barriers to entry.

The advantages offered by mobile technology, in terms of costs and potential effects on voting behaviour, could induce consultants and political leaders to an undifferentiated use of this tool. The present study evidenced that audience consensus, in terms of credibility and influence on the voting behaviour, relies on numerous factors, such as voters' inclination to the use of innovative communication media, their political affiliation, and their political attitudes and beliefs. It can also provide political marketing support for actors and operators willing to adopt new communication media to diffuse political information and obtain electoral success.

\section{Acknowledgments}

This research is part of my $\mathrm{PhD}$ dissertation, which was carried out at the University of Salento under the supervision of Professor Gianluigi Guido. I thank Professor Guido for his insightful comments and detailed advice, and Flaviano Mighali for his help in data collection and codification.

\section{References}

1 Kotler, P. and Kotler, N. (1999) 'Political marketing. Generating effective candidates, campaigns and causes', in Newman, B. (ed.), 'Handbook of Political Marketing', Sage, Thousand Oaks, CA.

2 Danyi, E. and Sukosd, M. (2003) 'Who is in control? Viral politics and control crisis in mobile election campaign', in Nyiri, K. (ed.), 'Mobile Democracy. Essays on Society, Self and Politics', Passagen Verlag, Vienna.

3 Denton, R. E. and Woodward, G. C. (1990) 'Political Communication in America', Praeger, New York.

4 McNair, B. (2003) 'An Introduction to Political Communication', Routledge, London.

5 Brownlow, S. (1990) 'Facial appearance, gender and credibility in television commercials., Journal of Nonverbal Behavior, Vol. 14 , pp. 51-60.

6 Self, C. S. (1996) 'Credibility', in Salwen, M. and Stacks, D. (eds), 'An Integrated Approach to Communication Theory and Research', Erlbaum, Mahway, NJ.

7 Ohanian, R. (1990) 'Construction and validation of a scale to measure celebrity endorser's perceived expertise, trustworthiness, and attractiveness', Journal of Advertising, Vol. 19, No. 3, pp. 39-52.

8 Mayer, R. C., Davis, J. H. and Schoorman, F. D. (1995) 'An integrative model of organizational trust', Academy of Management Review, Vol. 20, No. 3, pp. 709-734.

9 Cavazza, N. (1996) 'La Persuasione', Il Mulino, Bologna.

10 Lazarsfeld, P. F., Berelson, B. and Gaudet, H. (1944) 'The People's Choice: The Media in a Political Campaign', Columbia University Press, New York.

11 Schwartz, S. H. (1992) 'Universals in the content and structure of values: Theoretical advances and empirical tests in 20 countries', in Zanna, M. (ed.), 'Advances in Experimental Social Psychology', Academic Press, New York, No. 25, pp. 1-65.

12 Caprara, G. V. and Zimbardo, P. G. (2004) 'Personalizing politics: A congruency model of political preference', American Psychologist, Vol. 59, No. 7, pp. 581-594. 
13 Caprara, G. V., Barbaranelli, C., Vecchione, M., Testa, S., Loera, B. and Ricolfi, L. (2005) 'Quanto contano tratti, valori e preferenze morali nelle scelte di voto', Polena, Vol. 3, pp. 37-66.

14 Guido, G., Prete, M. I., Chirizzi, G. and Piscopiello, L. (2006) 'Personalità, valori e scelte di consumo degli elettori salentini: Uno studio di marketing politico', Paper presented at the VI National Conference SIPCO (Società Italiana di Psicologia di Comunità), 7-9 September, University of Salento, Lecce.

15 Digman, J. M. (1990) 'Personality structure: Emergence of the five factors model', Annual Review of Psychology, Vol. 41, pp. 417-440.

16 John, O. P. (1990) 'The 'Big Five' factor taxonomy: Dimension of personality in the natural language and in questionnaires', in Pervin, L.A. (ed.), 'Handbook of Personality: Theory and Research', Guilford, New York.

17 Kavanagh, D. (1995) 'Election Campaigning: The New Marketing of Politics', Blackwell Publishers, Oxford.
18 Diamond, E. and Bates, S. (1992) 'The Spot', MIT Press, Cambridge, Mass.

19 Johnson-Cartee, K. S. and Copeland, G. A. (1991) 'Negative Political Advertising: Coming of Age', Lawrence Erlbaum Associates, Hillsdale, NJ.

20 Dermody, J. and Scullion, R. (2005) 'Young people attitudes toward British political advertising: Nurturing or impeding voter engagement', in Wymer, W.W. and Lees-Marshment, J. (eds), 'Current Issues in Political Marketing', Haworth Press, Binghamton, NY.

21 Ansolabehere, S. and Iyengar, S. (1996) 'The craft of political advertising: A progress report', in Mutz, D.C., Sniderman, P.M. and Brody, R.A. (eds), 'Political Persuasion And Attitude Change', University of Michigan Press, Ann Arbor.

22 Gorsuch, R. (1983) 'Factor Analysis', Hillsdale, Erlbaum, NJ.

23 Caprara, G. and Vecchione, M. (2004) 'L'elettore infedele', Psicologia Contemporanea, Vol. 184 (July-August), pp. 4-9. 